\title{
Top classic citations in pancreatic cancer research
}

\author{
Qiang $\mathrm{Li}^{\mathrm{i}^{*}}$ and Yuan Jiang ${ }^{2}$
}

\begin{abstract}
Background: The number of times that articles are cited by is widely used to evaluate the impact of an article or an individual author has on its scientific community. This bibliometric analysis aimed to explore the top classic citations in pancreatic cancer $(P C)$ research.

Methods: A computerized literature search was conducted using the database, the Science Citation Index Expanded. The top 100 highly cited articles were included and further analyzed.

Results: The most cited article had 3,032 citations, with a mean of 626 citations per paper. These highly cited articles were published in 37 journals, led by Cancer Research (15 articles). Of the 100 articles, 40 were observational studies, 36 dealt with basic science, and 14 were randomized controlled trials. These articles came from 11 countries, with the USA contributing 79 articles. Fifty-one institutions produced these 100 citation classics, led by Johns Hopkins University (20 articles). Twenty-seven persons authored two or more of the top-cited articles, led by Kern SE (6) and Yeo CJ (5).
\end{abstract}

Conclusions: This analysis of the top highly cited articles allows for the recognition of major advances in PC research and gives a historic perspective on the progress of this specialty of PC research.

Keywords: Citation classic, Pancreatic cancer

\section{Background}

Currently, pancreatic cancer (PC) remains a fatal disease with poor prognosis [1]. In recent decades, significant growth has been seen in the field of pancreatic cancer research. Though these advancements in PC research are widely known by the clinicians, the most important papers are not commonly known and identified. Recently, many specialities and diseases have identified and analyzed their "citation classics" (the articles most highly cited or the articles cited more than 100 times) in their fields [2-6]. Besides, there were also a few journals which published their own citation classics $[7,8]$. The purpose of our present study was to identify the top classic citations in PC research.

\section{Methods}

A computerized literature search was conducted using the database, the Science Citation Index Expanded

\footnotetext{
* Correspondence: liqiangzhejiang@126.com

${ }^{1}$ Department of Emergency Medicine, Second Affiliated Hospital, School of

Medicine, Zhejiang University, Hangzhou 310009, China

Full list of author information is available at the end of the article
}

founded by the Institute for Scientific Information (1966-Sep 25, 2015) [9]. The relevant articles were identified by searching using a highly sensitive search strategy, and all phases of the search strategy are shown in Table 1. There was no journal restriction. The top 100 highly cited articles were included for further analysis.

The titles and abstracts of the articles would be reviewed to estimate whether they are related to PC research. We analyzed the articles and calculated the data according to the following predefined items: number of citations, publication year, country of origin, institution, journal, publication type (e.g., basic science, observational study), and authorship (only calculating the corresponding, first, and second author).

\section{Results}

The literature search involved 27,413 publications using the Science Citation Index Expanded founded by the Institute for Scientific Information (ISI) (1966-present). The top 100 highly cited articles were showed in Table 2 
Table 1 All phases of the search strategy to identify potential articles

title=(pancreatic or pancreas) AND title=(adenocarcinoma or adenocarcinomas or carcinoma or carcinomas or cancer or cancers or neoplasm or neoplasms or tumor or tumors or malignancy or malignancies)

according to the number of citation. The most frequently cited article received 3032 citations, and the least frequently cited article received 330 citations. Twelve articles received more than 1000 citations. The mean number of citations per paper was 626 . We also evaluated the 10 year citations of the paper published before 2006. The most frequently cited article received 1354 citations, and the least frequently cited article received 5 citations. The proportions of 10-year after publication of 1970-1979, 1980-1989, 1990-1999, and 2000-2005 were 20.5, 41.2, 49.8 , and $68.0 \%$, respectively (Table 3 ).

The top 100 classic citations were published from 1970 to 2013. The decade of 1990-1999 produced the most classic citations with 42 ones, followed by 37 ones from 2000 to 2009 (Fig. 1). The most classic papers published were 7 ones in 1993, 1997, 2004, and 2007.

The top-cited articles were published in 37 highimpact journals (Table 4), led by Cancer Research (15 articles), followed by Journal of Clinical Oncology (9), Annals of Surgery (9), and New England Journal of Medicine (8).

The 100 top-cited articles came from 11 countries, with the USA producing 79 articles, followed by UK with 6 ones, and Germany with 4 ones (Table 5). Altogether, 51 institutions produced these 100 topcited papers. Among them, 12 institutions produced 2 or more of the top-cited papers (Table 6), led by Johns Hopkins University (20 articles), followed by the University of Texas (7 articles), and Harvard University (7 articles).

In the 100 top-cited articles, 3 ones were authored by a single author and 5 ones by 2 authors. Twenty-seven persons authored two or more of the top citations. Table 6 presents a list of these "most frequent authors," which is led by Kern SE who authored 6 classic papers and Yeo CJ who authored 5 classic papers.

Of the 100 top-cited papers, 40 were observational studies, 36 dealt with basic science, and 14 were randomized controlled trials (RCT). The other 9 papers were 7 review articles, 1 conference consensus, and 1 meta-analysis (Table 7). Among the 56 clinical studies (40 observational studies, 14 RCTs, and 2 metaanalyses), 39 were about treatment (including 14 chemotherapy, 9 chemoradiotherapy, and 16 surgery), 9 were about diagnosis (2 radiographic and 8 laboratory), and 7 were about epidemiology (Table 8).

\section{Discussion}

Bibliometric analysis of most frequently cited articles and the journals in which they appear serves several purposes. It identifies and emphasizes the impact of the work of our colleagues and predecessors, recognizes key advances in pancreatic cancer research, and adds useful perspective on historical developments in this specialty. The use of citation analysis to examine the pancreatic cancer research literature also reveals quantitative information about authors, topics, and journals that is helpful in identifying classic works and high-impact journals. As far as we know, this is the first bibliometric analysis on the top citations in the field of pancreatic cancer research.

Although it is very difficult to provide a detailed analysis of all the 100 top citations, some interesting observations could be made about the top 10 . These 10 classic citations revealed major advances in PC research and a number of hot topics in the past five decades. The leading article by Burris HA 3rd reported the first largesize RCT on gemcitabine in advanced PC which may be the most important advance in the field of medical treatment of PC research in the past decades. At position 2, Moore MJ firstly described a large-size clinical RCT of erlotinib plus gemcitabine compared with gemcitabine alone in patients with advanced PC. At position 3 and 5, core signaling pathways revealed by global genomic analyses and mutant c-K-ras genes were reported. At position 4 and 9, identification of pancreatic cancer stem cells and the effect on tumor growth and metastatic activity of distinct populations of pancreatic cancer stem cells were described. At position 6, Guillemin R founded that growth hormone-releasing factor from a human pancreatic tumor could cause acromegaly. At position 7 , Conroy $\mathrm{T}$ conducted a RCT of FOLFIRINOX versus gemcitabine for metastatic pancreatic cancer. At position 8, Warshaw AL reviewed the advances of pancreatic cancer. At position 10, Neoptolemos JP compared chemoradiotherapy and chemotherapy after resection of pancreatic cancer in a RCT.

Most of the classic articles are still regularly cited now. Time has much effect on an article's citation, because of that an article's citations depend on its publication time, as citations accumulate over time. Hence, the group of the highly cited articles could be dominated by the earliest papers. However, the decade 1990-1999 and 20002009 produced the most classic citations with 42 and 37 ones, respectively, which indicated that much more advances were achieved in these two decades than the others, such as gemcitabine. Besides, in the most recent years, many new journals were developed, and therefore, the number of published articles has grown rapidly and more references are cited.

There were 15, 9, and 9 classic articles published in Cancer Research, Journal of Clinical Oncology, and 
Table 2 The top 100 cited articles in pancreas cancer research

\begin{tabular}{ll}
\hline Rank Article & No. of \\
& citations \\
\hline
\end{tabular}

1 Burris HA 3rd, Moore MJ, Andersen J, et al. Improvements in survival and clinical benefit with gemcitabine as first-line therapy for patients with advanced pancreas cancer: a randomized trial. J Clin Oncol. 1997;15(6):2403-2413.

2 Moore MJ, Goldstein D, Hamm J, et al. Erlotinib plus gemcitabine compared with gemcitabine alone in patients with advanced pancreatic cancer: a phase III trial of the National Cancer Institute of Canada Clinical Trials Group. J Clin Oncol. 2007;25(15):1960-1966.

3 Jones $\mathrm{S}$, Zhang $X$, Parsons DW, et al. Core signaling pathways in human pancreatic cancers revealed by global genomic analyses. Science. 2008;321(5897):1801-1806.

$4 \quad$ Li C, Heidt DG, Dalerba P, et al. Identification of pancreatic cancer stem cells. Cancer Res. 2007;67(3):1030-1037.

5 Almoguera C, Shibata D, Forrester K, et al. Most human carcinomas of the exocrine pancreas contain mutant C-K-ras genes. Cell. 1988;53(4):549-554.

6 Guillemin R, Brazeau P, Böhlen P, et al. Growth hormone-releasing factor from a human pancreatic tumor that caused acromegaly. Science. 1982;218(4572):585-587.

7 Conroy T, Desseigne F, Ychou M, et al. FOLFIRINOX versus gemcitabine for metastatic pancreatic cancer. N Engl J Med. 2011;364(19):1817-1825.

8 Warshaw AL, Fernández-del Castillo C. Pancreatic carcinoma. N Engl J Med. 1992;326(7):455-465.

9 Hermann PC, Huber SL, Herrler T, et al. Distinct populations of cancer stem cells determine tumor growth and metastatic activity in human pancreatic cancer. Cell Stem Cell. 2007;1(3):313-323.

10 Neoptolemos JP, Stocken DD, Friess $\mathrm{H}$, et al. A randomized trial of chemoradiotherapy and chemotherapy after resection of pancreatic cancer. N Engl J Med. 2004;350(12):1200-1210.

11 Olive KP, Jacobetz MA, Davidson CJ, et al. Inhibition of Hedgehog signaling enhances delivery of chemotherapy in a mouse model of pancreatic cancer. Science. 2009;324(5933):1457-1461.

12 Li D, Xie K, Wolff R, et al. Pancreatic cancer. Lancet. 2004;363(9414):1049-57.

13 Caldas C, Hahn SA, da Costa LT, et al. Frequent somatic mutations and homozygous deletions of the p16 (MTS1) gene in pancreatic adenocarcinoma. Nat Genet. 1994;8(1):27-32.

14 Oettle H, Post S, Neuhaus P, et al. Adjuvant chemotherapy with gemcitabine vs observation in patients undergoing curative-intent resection of pancreatic cancer - A Randomized controlled trial. JAMA. 2007;297(3):267-277.

15 Hidalgo M. Pancreatic cancer. N Engl J Med. 2010;362(17):1605-1617.

16 Lowenfels AB, Maisonneuve P, Cavallini G, et al. Pancreatitis and the risk of pancreatic cancer. N Engl J Med. 1993;328(20):1433-1437.

17 Thayer SP, di Magliano MP, Heiser PW, et al. Hedgehog is an early and late mediator of pancreatic cancer tumorigenesis. Nature. 2003:425(6960):851-856.

18 Hingorani SR, Petricoin EF, Maitra A, et al. Preinvasive and invasive ductal pancreatic cancer and its early detection in the mouse. Cancer Cell. 2003;4(6):437-435.

19 Liyanage UK, Moore TT, Joo HG, et al. Prevalence of regulatory T cells is increased in peripheral blood and tumor microenvironment of patients with pancreas or breast adenocarcinoma. J Immunol. 2002;169(5):2756-2761.

20 Sohn TA, Yeo CJ, Cameron JL, et al. Resected adenocarcinoma of the pancreas-616 patients: results, outcomes, and prognostic indicators. J Gastrointest Surg. 2000;4(6):567-579.

21 Yachida S, Jones S, Bozic I, et al. Distant metastasis occurs late during the genetic evolution of pancreatic cancer. Nature. 2010;467(7319):1114-1117.

22 Kalser MH, Ellenberg SS. Pancreatic cancer. Adjuvant combined radiation and chemotherapy following curative resection. Arch Surg. 1985;120(8):899-903.

23 Yeo CJ, Cameron JL, Lillemoe KD, et al. Pancreaticoduodenectomy for cancer of the head of the pancreas. 201 patients. Ann Surg. 1995;221(6):721-731.

24 Moertel CG, Frytak S, Hahn RG, et al. Therapy of locally unresectable pancreatic carcinoma: a randomized comparison of high dose (6000 rads) radiation alone, moderate dose radiation (4000 rads + 5-fluorouracil), and high dose radiation + 5-fluorouracil: The Gastrointestinal Tumor Study Group. Cancer. 1981;48(8):1705-1710.

25 Von Hoff DD, Ervin T, Arena FP, et al. Increased survival in pancreatic cancer with nab-paclitaxel plus gemcitabine. N Engl J Med. 2013;369(18):1691-1703

26 Klinkenbijl JH, Jeekel J, Sahmoud T, et al. Adjuvant radiotherapy and 5-fluorouracil after curative resection of cancer of the pancreas and periampullary region: phase III trial of the EORTC gastrointestinal tract cancer cooperative group. Ann Surg. 1999;230(6):776-782.

27 Hingorani SR, Wang L, Multani AS, et al. Trp53R172H and KrasG12D cooperate to promote chromosomal instability and widely metastatic pancreatic ductal adenocarcinoma in mice. Cancer Cell. 2005;7(5):469-483.

28 Bloomston M, Frankel WL, Petrocca F, et al. MicroRNA expression patterns to differentiate pancreatic adenocarcinoma from normal pancreas and chronic pancreatitis. JAMA. 2007;297(17):1901-1908. 
Table 2 The top 100 cited articles in pancreas cancer research (Continued)

29 Winter JM, Cameron JL, Campbell KA, et al. 1423 pancreaticoduodenectomies for pancreatic cancer: A single-institution experience. 633 J Gastrointest Surg. 2006;10(9):1199-1210.

30 Bardeesy N, DePinho RA. Pancreatic cancer biology and genetics. Nat Rev Cancer. 2002;2(12):897-909.

626

31 Louvet C, Labianca R, Hammel P, et al. Gemcitabine in combination with oxaliplatin compared with gemcitabine alone in locally advanced or metastatic pancreatic cancer: results of a GERCOR and GISCAD phase III trial. J Clin Oncol. 2005;23(15):3509-3516.

32 Cheng JQ, Ruggeri B, Klein WM, et al. Amplification of AKT2 in human pancreatic cells and inhibition of AKT2 expression and tumorigenicity by antisense RNA. Proc Natl Acad Sci U S A. 1996;93(8):3636-3641.

33 Tucker ON, Dannenberg AJ, Yang EK, et al. Cyclooxygenase-2 expression is up-regulated in human pancreatic cancer. Cancer Res. 1999:59(5):987-990.

34 Lee EJ, Gusev Y, Jiang J, et al. Expression profiling identifies microRNA signature in pancreatic cancer. Int J Cancer. 2007;120(5):1046-1054

35 Geer RJ, Brennan MF. Prognostic indicators for survival after resection of pancreatic adenocarcinoma. Am J Surg. 1993;165(1):68-72.

36 Magnani JL, Steplewski Z, Koprowski H, et al. Identification of the gastrointestinal and pancreatic cancer-associated antigen detected by monoclonal antibody 19-9 in the sera of patients as a mucin. Cancer Res. 1983;43(11):5489-5492.

37 Vincent A, Herman J, Schulick R, et al. Pancreatic cancer. Lancet. 2011;378(9791):607-620. Gudjonsson B. Cancer of the pancreas. 50 years of surgery. Cancer. 1987;60(9):2284-2303.

39 Hruban RH, van Mansfeld AD, Offerhaus GJ, et al. K-ras oncogene activation in adenocarcinoma of the human pancreas. A study of 82 carcinomas using a combination of mutant-enriched polymerase chain reaction analysis and allele-specific oligonucleotide hybridization. Am J Pathol. 1993;143(2):545-554.

40 Campbell PJ, Yachida S, Mudie $\sqcup$, et al. The patterns and dynamics of genomic instability in metastatic pancreatic cancer. Nature. 2010;467(7319):1109-1113.

41 Hruban RH, Takaori K, Klimstra DS, et al. An illustrated consensus on the classification of pancreatic intraepithelial neoplasia and intraductal papillary mucinous neoplasms. Am J Surg Pathol. 2004;28(8):977-987.

42 Smit VT, Boot AJ, Smits AM, et al. KRAS codon 12 mutations occur very frequently in pancreatic adenocarcinomas. Nucleic Acids Res. 1988;16(16):7773-7782.

43 Lowenfels AB, Maisonneuve P, DiMagno EP, et al. Hereditary pancreatitis and the risk of pancreatic cancer. International Hereditary Pancreatitis Study Group. J Natl Cancer Inst. 1997;89(6):442-446.

44 Wang W, Abbruzzese JL, Evans DB, et al. The nuclear factor-kappa B RelA transcription factor is constitutively activated in human pancreatic adenocarcinoma cells. Clin Cancer Res. 1999:5(1):119-127.

45 Huxley R, Ansary-Moghaddam A, Berrington de González A, et al. Type-ll diabetes and pancreatic cancer: a meta-analysis of 36 studies. Br J Cancer. 2005;92(11):2076-2083.

46 Han HJ, Yanagisawa A, Kato Y, et al. Genetic instability in pancreatic cancer and poorly differentiated type of gastric cancer. Cancer Res. 1993;53(21):5087-5089.

47 Hezel AF, Kimmelman AC, Stanger BZ, et al. Genetics and biology of pancreatic ductal adenocarcinoma. Genes Dev. 2006:20(10):1218-1249

48 Neoptolemos JP, Dunn JA, Stocken DD, et al. Adjuvant chemoradiotherapy and chemotherapy in resectable pancreatic cancer: a randomised controlled trial. Lancet. 2001;358(9293):1576-1585.

49 Sohn TA, Yeo CJ, Cameron JL, et al. Intraductal papillary mucinous neoplasms of the pancreas: an updated experience. Ann Surg. 2004;239(6):788-797.

50 Glimelius B, Hoffman K, Sjödén PO, et al. Chemotherapy improves survival and quality of life in advanced pancreatic and biliary cancer. Ann Oncol. 1996;7(6):593-600.

51 Dhillon N, Aggarwal BB, Newman RA, et al. Phase II trial of curcumin in patients with advanced pancreatic cancer. Clin Cancer Res. 2008;14(14):4491-4499.

52 Rozenblum E, Schutte M, Goggins M, et al. Tumor-suppressive pathways in pancreatic carcinoma. Cancer Res. 1997;57(9):1731-1734.

53 Berlin JD, Catalano P, Thomas JP, et al. Phase III study of gemcitabine in combination with fluorouracil versus gemcitabine alone in patients with advanced pancreatic carcinoma: Eastern Cooperative Oncology Group Trial E2297. J Clin Oncol. 2002;20(15):3270-3275.

54 Nitecki SS, Sarr MG, Colby TV, et al. Long-term survival after resection for ductal adenocarcinoma of the pancreas. Is it really improving? Ann Surg. 1995;221(1):59-66.

54 Aguirre AJ, Bardeesy N, Sinha M, et al. Activated Kras and Ink4a/Arf deficiency cooperate to produce metastatic pancreatic ductal adenocarcinoma. Genes Dev. 2003;17(24):3112-3126.

56 Conlon KC, Klimstra DS, Brennan MF. Long-term survival after curative resection for pancreatic ductal adenocarcinoma. Clinicopathologic analysis of 5-year survivors. Ann Surg. 1996;223(3):273-279.

57 Rothenberg ML, Moore MJ, Cripps MC, et al. A phase II trial of gemcitabine in patients with 5-FU-refractory pancreas cancer. Ann Oncol. 1996;7(4):347-353. 
Table 2 The top 100 cited articles in pancreas cancer research (Continued)

58 Sener SF, Fremgen A, Menck HR, et al. Pancreatic cancer: a report of treatment and survival trends for 100,313 patients diagnosed 458 from 1985-1995, using the National Cancer Database. J Am Coll Surg. 1999;189(1):1-7.

59 Beatty GL, Chiorean EG, Fishman MP, et al. CD40 agonists alter tumor stroma and show efficacy against pancreatic carcinoma in mice and humans. Science. 2011;331(6024):1612-1616.

60 Rhim AD, Mirek ET, Aiello NM, et al. EMT and dissemination precede pancreatic tumor formation. Cell. 2012;148(1-2):349-361.

1 Cameron JL, Crist DW, Sitzmann JV, et al. Factors influencing survival after pancreaticoduodenectomy for pancreatic cancer. Am J Surg. 1991;161(1):120-124.

62 Roldo C, Missiaglia E, Hagan JP, et al. MicroRNA expression abnormalities in pancreatic endocrine and acinar tumors are associated with distinctive pathologic features and clinical behavior. J Clin Oncol. 2006;24(29):4677-4684.

63 Yeo CJ, Abrams RA, Grochow LB, et al. Pancreaticoduodenectomy for pancreatic adenocarcinoma: postoperative adjuvant chemoradiation improves survival. A prospective, single-institution experience. Ann Surg. 1997;225(5):621-633.

64 Van Cutsem E, van de Velde $H$, Karasek P, et al. Phase III trial of gemcitabine plus tipifarnib compared with gemcitabine plus placebo in advanced pancreatic cancer. J Clin Oncol. 2004;22(8):1430-1438.

65 Pedrazzoli S, DiCarlo V, Dionigi R, et al. Standard versus extended lymphadenectomy associated with pancreatoduodenectomy in the surgical treatment of adenocarcinoma of the head of the pancreas: a multicenter, prospective, randomized study. Ann Surg. 1998;228(4):508-517.

66 Korc M, Chandrasekar B, Yamanaka Y, et al. Overexpression of the epidermal growth factor receptor in human pancreatic cancer is associated with concomitant increases in the levels of epidermal growth factor and transforming growth factor alpha. J Clin Invest. 1992;90(4):1352-1360.

67 Hruban RH, Goggins M, Parsons J, et al. Progression model for pancreatic cancer. Clin Cancer Res. 2000;6(8):2969-2972.

68 Feldmann G, Dhara S, Fendrich $V$, et al. Blockade of hedgehog signaling inhibits pancreatic cancer invasion and metastases: a new paradigm for combination therapy in solid cancers. Cancer Res. 2007;67(5):2187-2196.

69 Everhart J, Wright D. Diabetes mellitus as a risk factor for pancreatic cancer. A meta-analysis. JAMA. 1995;273(20):1605-1609.

70 Wagner $\mathrm{M}$, Redaelli C, Lietz $\mathrm{M}$, et al. Curative resection is the single most important factor determining outcome in patients with pancreatic adenocarcinoma. Br J Surg. 2004;91(5):586-594.

71 Friess $\mathrm{H}$, Yamanaka Y, Büchler $\mathrm{M}$, et al. Enhanced expression of transforming growth factor beta isoforms in pancreatic cancer correlates with decreased survival. Gastroenterology. 1993;105(6):1846-1856.

72 Warshaw AL, Gu ZY, Wittenberg J, et al. Preoperative staging and assessment of resectability of pancreatic cancer. Arch Surg. 1990;125(2):230-233.

73 Goggins M, Schutte M, Lu J, et al. Germline BRCA2 gene mutations in patients with apparently sporadic pancreatic carcinomas. Cancer Res. 1996;56(23):5360-5364.

74 Goldstein AM, Fraser MC, Struewing JP, et al. Increased risk of pancreatic cancer in melanoma-prone kindreds with p16INK4 mutations. N Engl J Med. 1995;333(15):970-974.

75 Chang KJ, Nguyen P, Erickson RA, et al. The clinical utility of endoscopic ultrasound-guided fine-needle aspiration in the diagnosis and staging of pancreatic carcinoma. Gastrointest Endosc. 1997;45(5):387-393.

76 Schutte $\mathrm{M}$, Hruban $\mathrm{RH}$, Geradts J, et al. Abrogation of the Rb/p16 tumor-suppressive pathway in virtually all pancreatic carcinomas Cancer Res. 1997;57(15):3126-3130.

77 Rösch T, Braig C, Gain T, et al. Staging of pancreatic and ampullary carcinoma by endoscopic ultrasonography. Comparison with conventional sonography, computed tomography, and angiography. Gastroenterology. 1992;102(1):188-199.

78 Bruns CJ, Solorzano CC, Harbison MT, et al. Blockade of the epidermal growth factor receptor signaling by a novel tyrosine kinase inhibitor leads to apoptosis of endothelial cells and therapy of human pancreatic carcinoma. Cancer Res. 2000;60(11):2926-2935.

79 Lan MS, Batra SK, Qi WN, et al. Cloning and sequencing of a human pancreatic tumor mucin CDNA. J Biol Chem. 1990;265(25):15294-15299.

80 MacMahon B, Yen S, Trichopoulos D, et al. Coffee and cancer of the pancreas. N Engl J Med. 1981;304(11):630-633.

81 Lieberman MD, Kilburn $\mathrm{H}$, Lindsey $\mathrm{M}$, et al. Relation of perioperative deaths to hospital volume among patients undergoing pancreatic resection for malignancy. Ann Surg. 1995;222(5):638-645.

82 Hwang RF, Moore T, Arumugam T, et al. Cancer-associated stromal fibroblasts promote pancreatic tumor progression. Cancer Res. 2008;68(3):918-926.

83 Rinehart J, Adjei AA, Lorusso PM, et al. Multicenter phase II study of the oral MEK inhibitor, Cl-1040, in patients with advanced non-small-cell lung, breast, colon, and pancreatic cancer. J Clin Oncol. 2004;22(22):4456-4462.

84 Regine WF, Winter KA, Abrams RA, et al. Fluorouracil vs gemcitabine chemotherapy before and after fluorouracil-based chemoradiation following resection of pancreatic adenocarcinoma: a randomized controlled trial. JAMA. 2008;299(9):1019-1026.

85 Bramhall SR, Allum WH, Jones AG, et al. Treatment and survival in 13,560 patients with pancreatic cancer, and incidence of the disease, in the West Midlands: an epidemiological study. Br J Surg. 1995;82(1):111-115. 
Table 2 The top 100 cited articles in pancreas cancer research (Continued)

85 Heinemann V, Quietzsch D, Gieseler F, et al. Randomized phase III trial of gemcitabine plus cisplatin compared with gemcitabine 364 alone in advanced pancreatic cancer. J Clin Oncol. 2006;24(24):3946-3952.

87 Tada M, Omata M, Kawai S, et al. Detection of ras gene mutations in pancreatic juice and peripheral blood of patients with pancreatic adenocarcinoma. Cancer Res. 1993;53(11):2472-2474.

88 Cullinan SA, Moertel CG, Fleming TR, et al. A comparison of three chemotherapeutic regimens in the treatment of advanced pancreatic and gastric carcinoma. Fluorouracil vs fluorouracil and doxorubicin vs fluorouracil, doxorubicin, and mitomycin. JAMA. 1985;253(14):2061-2067.

89 Logsdon CD, Simeone DM, Binkley C, et al. Molecular profiling of pancreatic adenocarcinoma and chronic pancreatitis identifies multiple genes differentially regulated in pancreatic cancer. Cancer Res. 2003;63(10):2649-2457.

90 Barton CM, Staddon SL, Hughes CM, et al. Abnormalities of the p53 tumour suppressor gene in human pancreatic cancer. Br J Cancer. 1991;64(6):1076-1082.

91 Casper ES, Green MR, Kelsen DP, et al. Phase II trial of gemcitabine (2,2'-difluorodeoxycytidine) in patients with adenocarcinoma of the pancreas. Invest New Drugs. 1994;12(1):29-34.

91 Mack TM, Yu MC, Hanisch R, et al. Pancreas cancer and smoking, beverage consumption, and past medical history. J Natl Cancer Inst. 1986;76(1):49-60.

93 Crile G Jr. The advantages of bypass operations over radical pancreatoduodenectomy in the treatment of pancreatic carcinoma. Surg Gynecol Obstet. 1970;130(6):1049-1053.

93 Yamanaka Y, Friess H, Kobrin MS, et al. Coexpression of epidermal growth factor receptor and ligands in human pancreatic cancer is associated with enhanced tumor aggressiveness. Anticancer Res. 1993;13(3):565-569.

95 Spitz FR, Abbruzzese JL, Lee JE, et al. Preoperative and postoperative chemoradiation strategies in patients treated with pancreaticoduodenectomy for adenocarcinoma of the pancreas. J Clin Oncol. 1997;15(3):928-937.

96 Sosa JA, Bowman HM, Gordon TA, et al. Importance of hospital volume in the overall management of pancreatic cancer. Ann Surg. 1998;228(3):429-438.

97 Redston MS, Caldas C, Seymour AB, et al. p53 mutations in pancreatic carcinoma and evidence of common involvement of homocopolymer tracts in DNA microdeletions. Cancer Res. 1994;54(11):3025-3033.

98 Pellegata NS, Sessa F, Renault B, et al. K-ras and p53 gene mutations in pancreatic cancer: ductal and nonductal tumors progress through different genetic lesions. Cancer Res. 1994;54(6):1556-1560.

99 Liebow C, Reilly C, Serrano M, et al. Somatostatin analogues inhibit growth of pancreatic cancer by stimulating tyrosine phosphatase. Proc Natl Acad Sci U S A. 1989;86(6):2003-2007.

100 Douglass HO. Further evidence of effective adjuvant combined radiation and chemotherapy following curative resection of pancreatic cancer. Gastrointestinal Tumor Study Group. Cancer. 1987;59(12):2006-2010.

Annals of Surgery, respectively, which showed that these three journals were the leading ones in the speciality of PC research. New England Journal of Medicine, Journal of the American Medical Association, and Lancet were the most famous general medical journals, and 16 articles were published in these three journals. The fact that papers on PC research are regularly published on these journals documents that $\mathrm{PC}$ is an important topic and health issue to humans.

The finding that most top-cited articles originated from the USA is anticipatory and is consistent with the origins

Table 3 10-year citations of the top-cited articles in pancreas cancer research

\begin{tabular}{lllll}
\hline & $\begin{array}{l}\text { Number } \\
\text { of papers }\end{array}$ & $\begin{array}{l}\text { Total } \\
\text { citations }\end{array}$ & $\begin{array}{l}\text { 10-year } \\
\text { citations }\end{array}$ & $\begin{array}{l}10 \text {-year/total } \\
(\%)\end{array}$ \\
\hline $1970-1979$ & 1 & 341 & 70 & 20.5 \\
$1980-1989$ & 12 & 7629 & 3145 & 41.2 \\
$1990-1999$ & 42 & 22,971 & 11,434 & 49.8 \\
$2000-2005$ & 21 & 12826 & 8718 & 68.0 \\
\hline
\end{tabular}

of the citation classics in other fields [2-5]. Furthermore, 11 of the 12 top productive institutions lie in USA. These findings confirm the USA's overwhelming impact on PC research because of its large population and abundant financial supports to the scientific community.

The list of the most frequent authors on PC research just gave a sample of some of the best recognized

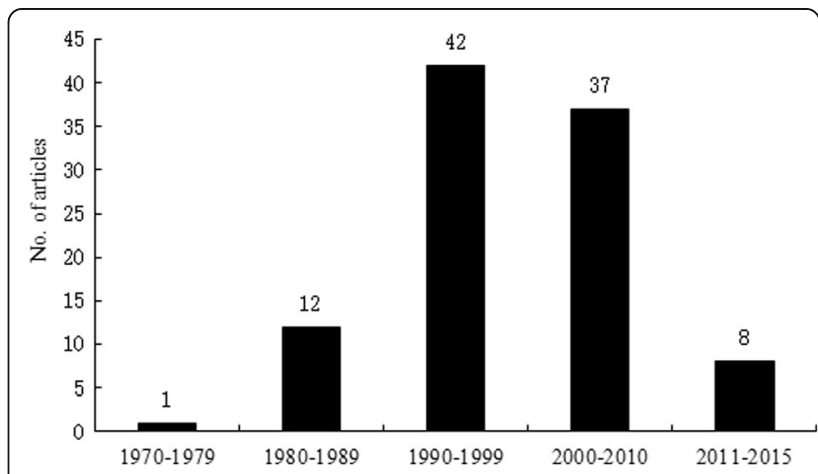

Fig. 1 The numbers of classic citations in the past decades 
Table 4 Journals in which the top 100 cited articles were published

\begin{tabular}{|c|c|c|}
\hline Rank & Journals & No. of articles \\
\hline 1 & Cancer Research & 15 \\
\hline 2 & Journal of Clinical Oncology & 9 \\
\hline 2 & Annals of Surgery & 9 \\
\hline 4 & New England Journal of Medicine & 8 \\
\hline 5 & Journal of the American Medical Association & 5 \\
\hline 6 & Science & 4 \\
\hline 7 & Nature & 3 \\
\hline 7 & Lancet & 3 \\
\hline 7 & Cancer & 3 \\
\hline 10 & Proceedings of the National Academy of Sciences & 2 \\
\hline 10 & Journal of the National Cancer Institute & 2 \\
\hline 10 & Journal of Gastrointestinal Surgery & 2 \\
\hline 10 & Genes \& Development & 2 \\
\hline 10 & Gastroenterology & 2 \\
\hline 10 & Clinical Cancer Research & 2 \\
\hline 10 & Cell & 2 \\
\hline 10 & Cancer Cell & 2 \\
\hline 10 & British Journal of Surgery & 2 \\
\hline 10 & British Journal of Cancer & 2 \\
\hline 10 & Archives of Surgery & 2 \\
\hline 10 & Annals of Oncology & 2 \\
\hline 10 & American Journal of Surgery & 2 \\
\hline 23 & Surgery, gynecology \& obstetrics & 1 \\
\hline 23 & Nucleic Acids Research & 1 \\
\hline 23 & Nature Reviews Cancer & 1 \\
\hline 23 & Nature Genetics & 1 \\
\hline 23 & Journal of Immunology & 1 \\
\hline 23 & Journal of Clinical Investigation & 1 \\
\hline 23 & Journal of Biological Chemistry & 1 \\
\hline 23 & Journal of the American College of Surgeons & 1 \\
\hline 23 & Investigational New Drugs & 1 \\
\hline 23 & International Journal of Cancer & 1 \\
\hline 23 & Gastrointestinal Endoscopy & 1 \\
\hline 23 & Cell Stem Cell & 1 \\
\hline 23 & Anticancer Research & 1 \\
\hline 23 & American Journal of Surgical Pathology & 1 \\
\hline 23 & American Journal of Pathology & 1 \\
\hline
\end{tabular}

scientists in PC research. It was not surprising that not all famous scientists in PC research were mentioned, which was consistent with the previous studies on top citation classics [2-5]. The editors may consider inviting these researchers to submit subsequent manuscripts
Table 5 Countries of origin of the top 100 cited articles

\begin{tabular}{lll}
\hline Rank & Countries & No. of articles \\
\hline 1 & USA & 79 \\
2 & UK & 6 \\
3 & Germany & 4 \\
4 & France & 2 \\
4 & Netherlands & 2 \\
6 & Australia & 1 \\
6 & Belgium & 1 \\
6 & Canada & 1 \\
6 & Italy & 1 \\
6 & Japan & 1 \\
6 & Sweden & 1 \\
\hline
\end{tabular}

or reviews. In many cross-discipline studies of highlycited articles, reviews usually predominate [10]. In this study, there were 7 reviews in the top 100 cited articles.

Some of the articles reported are not original research articles, except the reviews. They are highly cited because they are "opinion" articles, that for several reasons became classic in the field of pancreatology. For example, the article from Crile keeps being cited since it is an example of the so-called nihilistic approach to pancreatic cancer. Although they are not original research articles, they are also very important to the advance of pancreatic cancer, and thus, they are constantly cited.

In this literature analysis, by searching for "pancreatic cancer research", the top articles were mainly on oncology and basic cancer research. This paper maybe

Table 6 Institutions of origin with two or more top-cited articles

\begin{tabular}{lll}
\hline Rank & Institutions & $\begin{array}{l}\text { No. of } \\
\text { articles }\end{array}$ \\
\hline 1 & Johns Hopkins University & 20 \\
2 & University of Texas & 7 \\
2 & Harvard University & 7 \\
4 & Memorial Sloan-Kettering Cancer Center & 4 \\
4 & University of California, Irvine & 4 \\
4 & University of Pennsylvania & 4 \\
7 & Mayo Clinic Rochester & 3 \\
7 & Ohio State University & 3 \\
9 & Liverpool University & 2 \\
9 & National Institute of Arthritis, Diabetes, and Digestive & 2 \\
9 & and Kidney Diseases, NIH & 2 \\
9 & New York Medical College & 2 \\
\hline
\end{tabular}


Table 7 Most common authors of the top 100 cited articles

\begin{tabular}{|c|c|c|c|c|c|}
\hline Rank & Author & Corresponding & First & Second & Total \\
\hline 1 & Kern SE & 6 & - & - & 6 \\
\hline 2 & Yeo CJ & 4 & 1 & - & 5 \\
\hline 3 & Hruban RH & 2 & 1 & 1 & 4 \\
\hline 4 & Cameron JL & 2 & - & 2 & 4 \\
\hline 4 & Schutte M & - & 1 & 2 & 3 \\
\hline 4 & Neoptolemos JP & 2 & 1 & - & 3 \\
\hline 4 & Moore MJ & 1 & - & 2 & 3 \\
\hline 4 & Korc M & 3 & - & - & 3 \\
\hline 4 & Goggins M & 1 & 1 & 1 & 3 \\
\hline 4 & DePinho RA & 3 & - & - & 3 \\
\hline 4 & Brennan MF & 2 & - & 1 & 3 \\
\hline 4 & Abbruzzese $J L$ & 1 & - & 2 & 3 \\
\hline 13 & Yamanaka Y & - & 1 & 1 & 2 \\
\hline 13 & Yachida S & 1 & - & 1 & 2 \\
\hline 13 & Warshaw AL & 1 & 1 & - & 2 \\
\hline 13 & Von Hoff DD & 2 & - & - & 2 \\
\hline 13 & Tuveson DA & 2 & - & - & 2 \\
\hline 13 & Sohn TA & - & 1 & 1 & 2 \\
\hline 13 & Simeone DM & 1 & - & 1 & 2 \\
\hline 13 & Moertel CG & 1 & - & 1 & 2 \\
\hline 13 & Maisonneuve P & - & - & 2 & 2 \\
\hline 13 & Lowenfels AB & 2 & - & - & 2 \\
\hline 13 & Jones S & - & 1 & 1 & 2 \\
\hline 13 & Hingorani SR & 1 & 1 & - & 2 \\
\hline 13 & Friess $\mathrm{H}$ & - & 1 & 1 & 2 \\
\hline 13 & Caldas C & - & 1 & 1 & 2 \\
\hline 13 & Bardeesy N & - & 1 & 1 & 2 \\
\hline
\end{tabular}

just provides a good view of the medical part of the research world and does not fully reflect the great contribution to this field from surgeons. Some important surgical advances were achieved before several decades, when not many medical journals were published and the number of citations could not fully reflect the influence.

Table 8 Study design of the top 100 cited articles

\begin{tabular}{ll}
\hline Study design & No. of articles \\
\hline Observational study & 40 \\
Basic science & 36 \\
Randomized controlled trial & 14 \\
Review article & 7 \\
Conference consensus & 1 \\
Meta-analysis & 2 \\
\hline
\end{tabular}

\section{Conclusions}

The top-cited articles identify topics, authors, and institutions that contributed to major advances in the speciality of $\mathrm{PC}$ research. This analysis allows for the recognition of major advances in $\mathrm{PC}$ research and gives a historic perspective on the progress of PC research.

\section{Abbreviations}

PC: Pancreatic cancer; RCT: Randomized controlled trials

\section{Acknowledgements}

Not applicable.

Funding

Not applicable.

\section{Availability of data and materials}

The datasets during and/or analyzed during the current study are available from the corresponding author on reasonable request.

\section{Authors' contributions}

LQ designed this study, performed the literature search, and wrote the manuscript. JY performed the literature search and wrote the manuscript. Both authors read and approved the final manuscript.

Competing interests

The authors declare that they have no competing interests.

Consent for publication

Not applicable.

Ethics approval and consent to participate

Not applicable.

\section{Disclosure}

There are neither commercial interests nor financial and/or commercial support.

\section{Author details}

'Department of Emergency Medicine, Second Affiliated Hospital, School of Medicine, Zhejiang University, Hangzhou 310009, China. ${ }^{2}$ Department of Internal Medicine, Children's Hospital, School of Medicine, Zhejiang University, Hangzhou 310003, China.

Received: 23 November 2015 Accepted: 23 November 2016 Published online: 29 November 2016

\section{References}

1. Vincent A, Herman J, Schulick R, et al. Pancreatic cancer. Lancet. 2011;378:607-20.

2. Ho YS, Hartley J. Classic articles in psychology in the Science Citation Index Expanded: a bibliometric analysis. Br J Psychol. 2016;107:768-80.

3. Gu W, Yuan Y, Yang H, Qi G, Jin X, Yan J. A bibliometric analysis of the 100 most influential papers on COPD. Int J Chron Obstruct Pulmon Dis. 2015;10: $667-76$

4. Joyce CW, Sugrue CM, Joyce KM, Kelly JL, Regan PJ. 100 citation classics in the melanoma literature: a bibliometric analysis. Dermatol Surg. 2014 40:1284-98.

5. Tao T, Zhao X, Lou J, Bo L, Wang F, Li J, Deng X. The top cited clinical research articles on sepsis: a bibliometric analysis. Crit Care. 2012;16:R110.

6. Cao F, Li J, Li A, Fang Y, Li F. Citation classics in acute pancreatitis. Pancreatology. 2012;12:325-30.

7. Seiber JN. "Citation classics" and classic citations in JAFC. J Agric Food Chem. 2010;58:1-3.

8. Aronson JK. Citation classics in the British Journal of Clinical Pharmacology, 1974-2003. Br J Clin Pharmacol. 2004:58:5699-702.

9. Web of knowledge. ISI web of knowledge [homepage]. Available: http:// ipscience.thomsonreuters.com/. Accessed 15 June 2015.

10. Garfield E. 100 citation classics from the Journal of the American Medical Association. JAMA. 1987:257:52-9. 